\title{
DETERMINAN PERMODALAN BANK MELALUI PROFITABILITAS, RISIKO, UKURAN PERUSAHAAN, EFISIENSI DAN STRUKTUR AKTIVA
}

\author{
Sugeng Haryanto \\ Program D-III Keuangan dan Perbankan, Universitas Merdeka Malang \\ p3et@yahoo.com
}

\begin{abstract}
This study analyzes the influence of causality between the CAR, profitability, risk, company size, efficiency and asset structure of the banking industry. The sampling technique used in this research is purposive sampling, with the criteria of banks have gone public before 2008, publish the financial statements for 2008-2013. The total sample of 23 banks. The purpose of this study was to determine the effect of profitability, risk, company size, efficiency and capital structure of the bank's assets. The analysis technique used multiple linear regression. The results showed that the profitability, size and asset structure have the positive impact toward CAR. While the risk of bank have the negative impact toward CAR. Efficiency does not impact the CAR. The contribution of this study for the management of banking industry, researchers and regulators (Bank Indonesia) is that there is a must to increase CAR in order to increase the competitiveness of the national banking system.
\end{abstract}

Keywords: capital adequacy ratio, profitability, efficiency, risk, size

\begin{abstract}
ABSTRAK
Penelitian ini menganalisis kausalitas antara CAR, profitabilitas, risiko, ukuran perusahaan, efisiensi dan struktur aset industri perbankan. Teknik sampling yang digunakan dalam penelitian ini adalah purposive sampling dengan kriteria bank telah go public sebelum 2008 dan menerbitkan laporan keuangan 2008-2013. Total sampel adalah 23 bank. Tujuan dari penelitian ini adalah untuk mengetahui pengaruh profitabilitas, risiko, ukuran perusahaan, efisiensi dan struktur modal dari aset bank. Teknik analisis yang digunakan adalah regresi linier berganda. Hasil penelitian menunjukkan bahwa profitabilitas, ukuran dan struktur aktiva memiliki dampak positif terhadap CAR. Sementara itu, risiko bank memiliki dampak negatif terhadap CAR. Efisiensi tidak berdampak pada CAR. Kontribusi penelitian ini untuk pengelolaan industri perbankan, peneliti dan regulator (Bank Indonesia) adalah bahwa ada suatu keharusan untuk meningkatkan rasio kecukupan modal dalam rangka meningkatkan daya saing perbankan nasional.
\end{abstract}

Kata kunci: rasio kecukupan modal, profitabilitas, efisiensi, risiko, ukuran 


\section{PENDAHULUAN}

Riset Lindgreen (1996) menyatakan bahwa banyak negara yang perekonomiannya rusak sebagai akibat tidak sehatnya sistem perbankan. Keberadaan bank yang sehat merupakan prasyarat bagi suatu perekonomian yang sehat (Margaretha \& Setiyaningrum 2011). Bank berfungsi sebagai lembaga perantara keuangan (financial intermediary) yang menghubungan antara pihak-pihak yang memiliki kelebihan dana (surplus spending unit) dengan pihak-pihak yang memerlukan dana (deficit spending unit) serta lembaga yang berfungsi memperlancar aliran lalu lintas pembayaran. Sebagai financial intermediary fungsi dan peranan bank meliputi (Saunders \& Millon 2008) function as broker, function as asset transformers, role as delegated monitor, role as information producer. Fungsi-fungsi tersebut dapat berjalan dengan baik jika bank atau sistem perbankan itu yang sehat, baik secara individu maupun secara keseluruhan sebagai suatu sistem. Bank akan mampu menjalankan fungsi intermediasi dengan baik jika bank tersebut sehat. Ketika bank tidak sehat sehingga terjadi distorsi fungsi industri perbankan akan berakibat fungsi intermediasi terganggu, sehingga alokasi dan penyediaan dana untuk pembiayaan sektor-sektor produktif menjadi terbatas, lalu lintas pembayaran pembayaran yang dilakukan perbankan tidak lancar dan efektifitas kebijakan moneter terganggu (Utama 2006). Kesehatan suatu bank dapat diartikan sebagai kemampuan suatu bank untuk melakukan kegiatan operasional perbankan secara normal dan mampu memenuhi semua kewajibannya dengan baik dengan cara-cara yang sesuai dengan peraturan perbankan yang berlaku (Damayanti \& Chaniago 2014).

Peran penting bank sebagai lembaga intermediasi, dimana dana masyarakat menjadi penopang utama sumber pendanaan bank, maka industri perbankan merupakan industri dengan tingkat regulasi yang tinggi (highly regulated). Hal ini agar dana masyarakat aman, sehingga kepercayaan masyarakat terhadap bank terjaga. Fungsi intermediasi dapat berjalan dengan baik, manakala ada kepercayaan masyarakat terhadap bank, baik itu deposan maupun shareholder yang lain. Kepercayaan deposan muncul ketika deposan merasa aman menyimpan dananya di bank. Brinkmann dan Horvitz (1995) tingginya modal yang dimiliki bank efektif melindungi depositor (sistem asuransi simpanan) terhadap kegagalan bank. Kepercayaan merupakan modal yang sangat penting bagi bank.

Salah satu permasalahan yang menjadi prioritas bank adalah permodalan. Permodalan merupakan salah satu aspek penilaian kesehatan suatu bank. Capital adequacy atau kecukupan modal merupakan komponen penting dalam menilai tingkat kesehatan bank (Whalen \& Thomson 1988). Bank Indonesia sesuai dengan ketentuan Bank of International Settlement (BIS) telah menetapkan rasio kecukupan modal bank atau dikenal dengan capital adequacy ratio (CAR) minimal sebesar 8 persen. Peranan modal sangat penting dalam usaha perbankan karena dapat mendukung kegiatan oprasional bank agar dapat berjalan dengan lancar (Sari 2013). Bank dengan CAR cukup besar diharapkan mampu untuk mendukung pengembangan operasi dan kelangsungan hidup bank, menutup risiko yang terjadi dan memberikan insentif bagi pemilik untuk 
menjaga kepentingannya dalam bank. Dendawijaya (2005) semakin tinggi nilai CAR mengindikasikan bahwa bank telah mempunyai modal yang cukup baik dalam menunjang kebutuhannya serta menanggung risiko-risiko yang ditimbulkan termasuk di dalamnya risiko kredit. Sehingga bank dengan CAR yang besar cenderung akan mampu meningkatkan kepercayaan masyarakat terhadap bank tersebut.

Permodalan bank pada tahun 2011 mengalami penurunan, namun sejak tahun 2011-2014 cenderung mengalami peningkatan (Tabel 1). Hasil stress test risiko pasar menunjukkan bahwa CAR industri perbankan masih berada di atas 14 persen (Bank Indonesia 2014). CAR bank yang berada diatas 14 persen menunjukkan industri perbankan nasional masih memiliki ketahanan yang tinggi.

Tabel 1

CAR Bank Nasional 2010-2014

\begin{tabular}{cc}
\hline Tahun & CAR \\
\hline 2010 & 17,2 \\
2011 & 16,1 \\
2012 & 17,4 \\
2013 & 18,4 \\
2014 & 19,5 \\
\hline Sumber: Bank Indonesia $(2015,2014,2013,2012,2011)$
\end{tabular}

CAR bank di Indonesia sampai dengan semester I 2015 telah mencapai 20,3 persen, atau lebih tinggi dari Malaysia 14,9 persen dan Thailand 16,5 persen. Sementara ROA perbankan nasional pada Semester I 2015 mencapai 2,3 persen, lebih tinggi dari Thailand atau Fillipina yang nilainya masih di bawah 2 persen. Namun demikian dari sisi aset perbankan masih relatif kecil di bandingkan dengan aset perbankan di negara-negara ASEAN. Total aset Bank Mandiri sebagai bank terbesar di Indonesia hanya mencapai Rp888 Triliun, jauh di bawah DBS Bank, May Bank atau Krung Thai yang masing-masing mencapai Rp5,970 Triliun, Rp2,331 Triliun dan Rp1,162 Triliun (Sindonews.com).

Tabel 2

CAR dan Aset Empat Bank Terbesar Tahun 2014

\begin{tabular}{lcc}
\hline \multicolumn{1}{c}{ Nama Bank } & $\begin{array}{c}\text { Aset (Trilyun } \\
\text { Rupiah) }\end{array}$ & $\begin{array}{c}\text { CAR } \\
(\boldsymbol{\%})\end{array}$ \\
\hline Mandiri & 855 & 16,20 \\
BBRI & 802 & 18,31 \\
BCA & 552 & 17,24 \\
BNI & 417 & 16,22 \\
\hline Sumber: idx
\end{tabular}

Kompetisi perbankan global menuntut bank tidak hanya besar secara aset namun juga kuat dalam permodalan. Pada tahun 2019 hanya bank-bank yang mampu memenuhi kriteria Qualified Asean Bank (QAB) yang dapat melakukan ekspansi ke seluruh Negara ASEAN. Hal tersebut membuat kompetisi perbankan nasional akan semakin tinggi dan 
bank nasional akan dapat beroperasi di Negara-negara ASEAN. Salah satu kriteria adalah bank harus memiliki rasio kecukupan modal atau CAR sesuai Basel III minimal 17,5 persen di tahun 2019. Industri perbankan nasional dilihat secara aset masih berada jauh di bawah bank-bank di Negara-negara ASEAN lainnya. CAR empat bank dengan aset terbesar sampai dengan Desember 2014 menunjukkan masih berada di bawah ketentuan untuk masuk QAB (Tabel 2). Perbankan nasional tentunya dituntut untuk mampu meningkatkan CAR-nya, sehingga mampu bersaing dalam persaingan industri perbankan secara global. Kondisi demikian menunjukkan bahwa secara tidak langsung Indonesia merupakan pasar potensial bagi bank dari negara-negara lain, dengan aset dan permodalan yang besar. Karena CAR dan aset industri perbankan yang masih di bawah ketentuan QAB. Sedangkan bank nasional jika tidak mampu memenuhi ketentuan QAB hanya dapat beroperasi di pasar Indonesia. Kompetisi industri perbankan nasional akan semakin ketat seiring dengan masuknya bank-bank asing yang telah memenuhi ketentuan QAB di industri perbankan nasional. Dalam era persaingan bebas, kondisi demikian tentunya akan berpengaruh terhadap daya saing bagi industri perbankan nasional dalam persaingan bisnis perbankan secara global.

Perbankan nasional selain harus meningkatkan asetnya juga harus meningkatkan CAR. Tingkat kebutuhan CAR bank adalah masalah mendasar tidak hanya di Indonesia, tetapi juga di semua negara. Upaya meningkatkan CAR bank bukan hanya dalam upaya memenuhi ketentuan Otoritas Moneter (Bank Indonesia) tetapi juga dalam upaya bagaimana industri perbankan nasional menghadapi persaingan global dalam dunia perbankan. Selain itu CAR yang tinggi dalam upaya agar bank tidak rentan ketika kondisi lingkungan bisnis yang bergejolak.

Hasil riset terhadap faktor yang memengaruhi CAR suatu bank menunjukkan hasil yang tidak konsisten. Penelitian Shingjergji dan Marsida Hyseni (2015) faktor yang memengaruhi CAR adalah Return on Assets (ROA), Return on Equity (ROE), the Non Performing Loans (NPL) dan bank size (Total Assets), Equity Multiplier (EM) dan Loan to Deposit Ratio (LTD). Hasil penelitian menunjukkan bahwa profitabilitas tidak berpengaruh terhadap CAR bank di Albania. Hasil penelitian yang dilakukan Polat dan Al-khalaf faktor yang memengaruhi CAR adalah Loan to Deposit Ratio (LTD), Loans, NPL, ROA, leverage dan Devident Pay Out Ratio (DPR). Dimana hasil penelitian ini menunjukkan bahwa faktor NPL berpengaruh terhadap CAR bank di Arab Saudi. Irawan dan Anggono (2015) menunjukkan Aset, ROA, ROE, NIM, Kredit, Deposit, dan NPL berpengaruh terhadap CAR, sedangkan Liquidity Coverage Ratio (LCR) tidak berpengaruh terhadap CAR.

Penelitian Muyanja Ssenyonga dan Prabowo (2006), Aini (2013) menunjukkan bukti pentingnya CAR bagi bank dalam mengembangkan usahanya dan menampung risiko serta menghindari likuidasi dan kebangkrutan. Almilia dan Herdinigtyas (2005) CAR mempunyai pengaruh terhadap kondisi bermasalah dan pengaruhnya negatif, artinya semakin rendah rasio CAR kemungkinan bank dalam kondisi bermasalah semakin besar. 
Return on Asset (ROA) merupakan indikator profitabilitas yang sering digunakan untuk menilai profitabilitas bank. Bank Indonesia selaku pembina dan pengawas perbankan lebih mengutamakan nilai profitabilitas suatu bank yang diukur dari nilai aset yang dananya sebagian besar berasal dari dana masyarakat atau dana pihak ketiga (DPK). ROA digunakan untuk mengukur efisiensi dan efektifitas perusahaan didalam menghasilkan keuntungan dengan memanfaatkan aktiva yang dimilikinya. Semakin tinggi profitabilitas bank, menunjukkan semakin tinggi laba yang diperoleh, maka akan meningkatkan modal bank tersebut. Hal ini terjadi manakala laba tersebut ditanamkan kembali dalam modal dalam bentuk laba ditahan. Sebaliknya jika bank mengalami kerugian, maka akan mengurangi modalnya. Hasil penelitian pengaruh profitabilitas terhadap CAR menunjukkan bahwa hasil yang berbeda. Fatimah (2014) memberi temuan empiris bahwa ROA berpengaruh negatif terhadap CAR, sedangkan hasil penelitian Ali (2006) dan F. Artin Shitawati (2006) menunjukkan bahwa profitabilitas berpengaruh positif terhadap permodalan bank.

Bank selain berusaha memperoleh laba yang tinggi, sehingga profitabilitasnya tinggi juga harus mampu menjaga risiko yang mungkin terjadi atas penyaluran kredit yang diberikannya. Dengan kata lain, bank harus mampu mengelola kegiatannya dengan sebaik-baiknya, agar tujuan perusahaan tercapai. Lingkungan bisnis, baik lingkungan eksternal maupun internal perbankan mengalami perkembangan pesat yang akan diikuti oleh semakin kompleksnya risiko bagi kegiatan usaha perbankan. Salah satu risiko yang muncul akibat semakin kompleksnya kegiatan perbankan adalah munculnya Non Performing Loan (NPL) yang semakin besar. Dengan kata lain semakin besar skala operasi suatu bank, maka aspek pengawasan semakin menurun, sehingga NPL semakin besar, yang berarti risiko semakin besar.

NPL mencerminkan risiko kredit, dimana semakin kecil NPL semakin kecil pula risiko kredit yang ditanggung pihak bank. Bank dengan NPL yang tinggi akan cenderung harus menyediakan modal yang besar dalam upaya mengcover risiko tersebut. Penelitian menunjukkan hasil yang berbeda, penelitian Usman (2003) menunjukkan bahwa NPL tidak berpengaruh signifikan terhadap CAR. Damayanti dan Chaniago (2014) NPL tidak berpengaruh terhadap tingkat kesehatan bank. Sedangkan Krisna (2008) NPL berpengaruh terhadap CAR.

Ukuran perusahaan menunjukkan besarnya aset yang dimiliki bank, jumlah penjualan, rata-rata total penjualan dan rata-rata asets. Ukuran perusahaaan menunjukkan jumlah pengalaman dan kemampuan tumbuhnya suatu perusahaan yang mengindikasikan kemampuan dan tingkat risiko dalam mengelola investasi yang diberikan para stockholder untuk meningkatkan kemakmuran investor. Hal ini menunjukkan bahwa perusahaan besar lebih menjanjikan kinerja yang baik (Kunlin 2007). Salah satu indikator untuk mengukur besarnya kecilnya perusahaan adalah ukuran aktiva dari perusahaan tersebut. Perusahaan yang memiliki total aktiva besar menunjukkan bahwa perusahaan tersebut telah mencapai tahap kedewasaan dimana dalam tahap ini ukuran perusahaan sudah positif dan dianggap memiliki prospek yang baik dalam jangka waktu yang relatif 
lama, selain itu juga mencerminkan bahwa perusahaan relatif lebih stabil dan lebih mampu menghasilkan laba dibanding perusahaan dengan total aset yang kecil (Pangemanan \& Mawikere 2011).

Aktiva bank merupakan wujud dari penempatan atau investasi dana bank dalam berbagai bentuk yang diharapkan akan mampu mengoptimalkan nilai perusahaan dalam jangka pendek maupun jangka panjang. Salah satu komponen besar dalam aktiva bank adalah kredit yang disalurkan. Semakin besar jumlah kredit yang disalur bank dituntut untuk meningkatkan permodalannya dalam rangka mengcover risiko kredit yang disalurkan. Hal ini menunjukkan bahwa semakin besar ukuran perusahaan maka cenderung akan meningkatkan CAR bank. Beberapa hasil penelitian menunjukkan hasil yang tidak konsisten. Ahmad et al. (2008) menyatakan Ukuran bank (Size) dalam hubungannya dengan total aset yang dimiliki dan tingkat likuiditas bank merupakan faktor penting dalam menentukan rasio permodalan. Sedangkan Godlewski (2005), Margaretha dan Setiyaningrum (2011) menunjukkan bahwa ukuran bank tidak berpengaruh terhadap CAR.

Efisiensi merupakan determinan kunci dalam aktivitas operasional suatu perusahaan. Efisiensi pada industri perbankan secara keseluruhan merupakan aspek yang penting diperhatikan dalam upaya mewujudkan suatu kinerja bank yang sehat dan berkelanjutan. Persaingan dalam industri perbankan yang sangat ketat menuntut bank harus mampu meningkatkan efisiennya dalam kegiatan operasinya. Salah satu indikator untuk mengukur efisiensi bank dapat digunakan BOPO. BOPO merupakan rasio perbandingan biaya operasional terhadap pendapatan operasional. Rasio ini digunakan untuk mengukur tingkat efisiensi dan kemampuan bank dalam melakukan kegiatan operasinya terutama kredit (Dendawijaya 2005). BOPO yang tinggi menunjukkan bank kurang efisien. Rasio BOPO yang tinggi menunjukkan bank tidak dapat mengelola sumber dana dan aktiva yang dimiliki untuk memperoleh laba. Rasio BOPO yang tinggi dapat mengikis modal bank sehingga dapat mengganggu kesehatan bank.

Beberapa hasil penelitian menunjukkan bahwa efisiensi bank berpengaruh terhadap permodalan bank (CAR). F. Artin Shitawati (2006), Ghosh et al. (2003) efisiensi berpengaruh terhadap rasio kecukupan modal. Ahmad et al. (2008) efisensi biaya operasional akan menambah modal bank. Sedangkan penelitian Krisna (2008), Fitrianto dan Mawardi (2006) menyatakan bahwa rasio BOPO tidak berpengaruh terhadap rasio kecukupan modal.

Perusahaan, khusunya pihak manajemen selain dituntut untuk dapat mengambil kebijakan bagaimana struktur modal perusahaan, juga dituntut untuk dapat menggunakan sumber dana atau modal yang diperoleh untuk ditempatkan dalam aktiva lancar dan aktiva tetapnya. Jika struktur modal perusahaan akan sangat terkait dengan biaya modal, maka struktur aktiva akan sangat terkait dengan karakteristik sumber dana dan return serta risiko penempatan atau penggunaan dana tersebut. Kebijakan struktur aktiva yang 
baik, diharapkan akan mampu memberikan keuntungan bagi perusahaan dalam jangka pendek maupun jangka panjang.

Menurut Kholifah (2013) struktur aktiva merupakan variabel yang penting dalam keputusan pendanaan perusahaan, karena dalam struktur aktiva terdapat aktiva tetap yang digunakan sebagai jaminan (collateral) bagi pihak kreditur. Struktur aktiva adalah kekayaan atau sumber-sumber ekonomi yang dimiliki oleh perusahaan yang diharapkan akan memberi manfaat di masa yang akan datang. Bank dengan mengetahui karakteristik dari sumber dananya akan dapat menempatkan dana tersebut sesuai dengan karakteritiknya. Bank akan banyak menempatkan dananya untuk aktiva tetap tentunya dari dana-dana yang sifatnya jangka panjang, terutama dari modal sendiri. Sehingga semakin besar struktur aktiva akan berpengaruh pada CAR bank. Pertanyaan penelitian ini adalah bagaimana pengaruh masing-masing variabel profitabilitas, risiko, ukuran perusahaan, efisiensi dan struktur aktiva terhadap CAR?

Diharapkan dari penelitian ini dapat memberikan kontribusi bagi Bank diharapkan dapat digunakan bank untuk menentukan besarnya permodalan (CAR) dan bagi peneliti sebagai bahan kajian tentang operasional bank, khususnya terkait dengan analisis permodalan bank.

\section{KAJIAN PUSTAKA DAN PERUMUSAN HIPOTESIS \\ Capital Adequacy Ratio (CAR)}

Peranan modal sangat penting dalam usaha perbankan karena dapat mendukung kegiatan operasional bank agar dapat berjalan dengan lancar (Fira Puspita 2009). Hempel dan Yawitz (1977) menyatakan bahwa kebutuhan permodalansari bank cenderung akan selalu meningkat, hal ini karena pertumbuhan aset dan dana simpanan masyarakat, persyaratan rasio kecukupan modal dari pihak yang berwewenang dan ketersediaan serta biaya modal bank. Permodalan bank diatur dengan rasio kecukupan modal atau CAR. CAR merupakan rasio kecukupan modal yang menunjukkan kemampuan bank dalam mempertahankan modal yang mencukupi dan kemampuan manajemen bank dalam mengidentifikasi, mengukur, mengawasi dan mengontrol risiko-risiko yang timbul yang dapat berpengaruh terhadap besarnya modal (Almilia dan Herdinigtyas 2005). (Idroes (2011) menyatakan bahwa CAR mencerminkan kemampuan bank untuk menutup risiko kerugian dari aktivitas yang dilakukannya dan kemampuan bank dalam mendanai kegiatan operasionalnya. Bank dengan rasio CAR yang semakin besar, menunjukkan semakin baik kemampuan bank untuk menanggung risiko dari setiap kredit atau aktiva produktif yang berisiko.

\section{Profitabilitas Bank terhadap CAR}

Manajemen sebagai agen yang diberikan kewenangan oleh pemilik perusahaan mempunyai tugas mengelola berbagai sumber daya (resources) yang dimiliki perusahaan 
secara efektif dan efisien untuk lebih meningkatkan kinerja operasi dimana perusahaan tujuan bagaimana mencapai profitabilitas yang tinggi. Profitabilitas merupakan indikator yang paling tepat untuk mengukur kinerja bank. Pada umumnya analis keuangan menggunakan dua indikator untuk menilai profitabilitas suatu perusahaan, yaitu return on equity (ROE) dan return on aset (ROA). Bank Indonesia lebih mengutamakan nilai profitabilitas suatu bank yang diukur dari nilai aset yaitu ROA. Hal ini karena aset bank sebagian besar berasal DPK. ROA digunakan untuk mengukur efisiensi dan efektifitas perusahaan dalam menghasilkan keuntungan dengan memanfaatkan aktiva yang dimilikinya. Tingginya ROA mengindikasikan bahwa bank semakin baik dalam penggunaan aset yang dimilikinya, untuk memperoleh laba. Semakin tinggi laba cenderung akan mampu meningkatkan permodalan bank, melalui laba yang ditahan.

Beberapa penelitian pada industri perbankan di beberapa negara menunjukkan bahwa profitabilitas berpengaruh terhadap ROA. Hasil menunjukkan Ali (2006), F. Artin Shitawati (2006), Polat dan Al-khalaf (2014), Irawan dan Anggono (2015) menunjukkan profitabilitas bank berpengaruh terhadap CAR.

H1: Profitabilitas (ROA) berpengaruh terhadap CAR.

\section{Risiko (Non Performance Loan) terhadap CAR}

Risiko merupakan bentuk keadaan ketidakpastian tentang suatu keadaan yang akan terjadi nantinya dengan keputusan yang diambil berdasarkan pertimbangan pada saat ini (Fahmi 2010:2). Risiko usaha bank atau business risk merupakan tingkat ketidakpastian atau potensi timbulnya kerugian atas kegiatan usaha yang dilakukan oleh bank. Risiko usaha bank meliputi risiko kredit, risiko pasar, pasar likuiditas, risiko operasional, risiko hukum, risiko stratejik, risiko kepatuhan dan risiko reputasi. Risiko kredit merupakan potensi kerugian yang timbul akibat kegagalan counterparty dalam memenuhi kewajiban kepada Bank. NPL merupakan indikator yang sering dipakai untuk mengukur risiko kredit. NPL merupakan perbandingan antara kredit bermasalah dengan total kredit yang disalurkan bank. Semakin tinggi NPL menunjukkan semakin tinggi risikonya. Untuk mengcover risiko bank harus menyediakan permodalan yang cukup. Artinya semakin tinggi risiko maka akan cenderung semakin tinggi CAR. Penelitian Krisna (2008), Shingjergji dan Marsida Hyseni (2015) dan Irawan dan Anggono (2015) NPL berpengaruh terhadap CAR.

H2: Risiko (NPL) berpengaruh terhadap CAR.

\section{Ukuran Perusahaan (Size) terhadap CAR}

Ukuran perusahaan menggambarkan besar kecilnya suatu perusahaan yang dapat dinilai dari total aset yang dimiliki, jumlah penjualan, rata-rata total penjualan dan ratarata aset. Perusahaan yang memiliki total aktiva besar menunjukkan perusahaan tersebut telah mencapai tahap kedewasaan dimana dalam tahap ini arus kas perusahaan sudah positif dan dianggap memiliki prospek yang baik dalam jangka waktu yang relatif lama, 
selain itu juga mencerminkan bahwa perusahaan relatif lebih stabil dan lebih mampu menghasilkan laba dibanding perusahaan dengan total aset yang kecil (Pangemanan \& Mawikere 2011). Ukuran perusahaaan menunjukkan jumlah pengalaman dan kemampuan tumbuhnya suatu perusahaan yang mengindikasikan kemampuan dan tingkat risiko dalam mengelola investasi yang diberikan para stockholder untuk meningkatkan kemakmuran. Hal ini menunjukkan bahwa perusahaan besar lebih menjanjikan kinerja yang baik (Kunlin 2007).

Ukuran perusahaan menggambarkan besar kecilnya suatu perusahaan yang dapat dinilai dari total aset yang dimiliki perusahaan. Ada beberapa proksi yang digunakan untuk mengukur ukuran perusahaan. Naiker et al. (2008) menggunakan perhitungan nilai logaritma total aktiva. Sedangkan Hall dan Weiss (1967) menggunakan perhitungan nilai 1/logaritma total aktiva. Size bank berpengaruh terhadap CAR. Hasil penelitian (Ahmad et al. (2008) menunjukkan ukuran bank tidak berpengaruh signifikan terhadap rasio kecukupan modal, sedangkan penelitian Godlewski (2005) menunjukkan bahwa ukuran bank berpengaruh terhadap permodalan bank.

H3: Ukuran bank berpengaruh terhadap CAR.

\section{Efisiensi (BOPO)}

Efisiensi merupakan indikator penting dalam mengukur kinerja keseluruhan dari aktivitas suatu perusahaan. Dimana efisiensi adalah salah satu ukuran kinerja yang secara teoretis mendasari seluruh kinerja sebuah organisasi dengan mengacu pada filosofi kemampuan menghasilkan output yang optimal dengan input-nya yang ada. Efisiensi akan terkait dengan pengelolaan hubungan input dan output yaitu bagaimana mengalokasikan faktor-faktor produksi yang tersedia secara optimal untuk dapat menghasilkan output yang maksimal. Efisiensi bank merupakan aspek yang paling penting diperhatikan untuk mewujudkan suatu kinerja keuangan yang sehat dan berkelanjutan (sustainable).

BOPO merupakan rasio antara biaya operasional terhadap pendapatan operasional. Menurut Dendawijaya (2005) merupakan rasio biaya operasional digunakan untuk mengukur tingkat efisiensi dan kemampuan bank dalam melakukan kegiatan operasinya. Efisiensi industri perbankan dapat ditinjau dari sudut pandang mikro maupun makro (Berger dan Mester 1997). Dari perspektif mikro, dalam suasana persaingan yang semakin ketat sebuah bank agar bisa bertahan dan berkembang harus efisien dalam kegiatan operasinya. Bank-bank yang tidak efisien, besar kemungkinan akan exit dari pasar karena tidak mampu bersaing dengan kompetitornya, baik dari segi harga (pricing) maupun dalam hal kualitas produk dan pelayanan.

Rasio BOPO yang tinggi menunjukkan bahwa bank tidak dapat mengelola sumber dana dan aktiva yang dimiliki untuk memperoleh laba. Rasio BOPO yang tinggi akan dapat mengikis modal bank sehingga dapat mengganggu kesehatan bank. Standar rasio BOPO yang aman menurut Bank Indonesia adalah berkisar antara 94 persen sampai 
dengan 96 persen. Hasil penelitian Ghosh et al. (2003) dan Ahmad et al. (2008) efisensi biaya berpengaruh terhadap modal bank.

H4: Efisensi bank berpengaruh terhadap CAR.

\section{Struktur Aktiva}

Kekayaaan perusahaan tercermin dari aset perusahaan, yang terdiri dari aktiva tetap, aktiva tidak berwujud, aktiva lancar, dan aktiva tidak lancar. Pandey (2002) mendefinisikan struktur aktiva sebagai perbandingan antara aktiva tetap dengan total aktiva yang dimiliki oleh perusahaan. Struktur aktiva terdiri dari aktiva lancar dan aktiva tetap (Agus Sartono 2008). Aktiva lancar adalah harta atau kekayaan yang segera dapat diuangkan (ditunaikan) pada saat dibutuhkan dan paling lama satu tahun. Sedangkan aktiva tetap adalah harta atau kekayaan perusahaan yang digunakan dalam jangka panjang lebih dari satu tahun. Menurut J. Fred Weston dan T.E. Copeland (1997), struktur aktiva memengaruhi sumber-sumber pembiayaan melalui beberapa cara. Perusahaan yang sebagian besar aktivanya berupa aktiva lancar, tidak begitu bergantung pada pembiayaan utang jangka panjang dan lebih tergantung pada pembiayaan jangka pendek.

Perusahaan dengan struktur aktiva besar, akan menggunakan hutang jangka panjang lebih banyak karena aktiva tetap yang ada dapat digunakan sebagai jaminan hutang Eugene F. Brigham (2011) Struktur aktiva akan menentukan seberapa besar hutang jangka panjang yang dapat dilakukan, sehingga akan berpengaruh juga terhadap penentuan besarnya struktur modal.

H5: Struktur aktiva berpengaruh terhadap CAR.

\section{Kerangka Pikir}

Model dalam penelitian ini dapat digambarkan sebagai berikut:

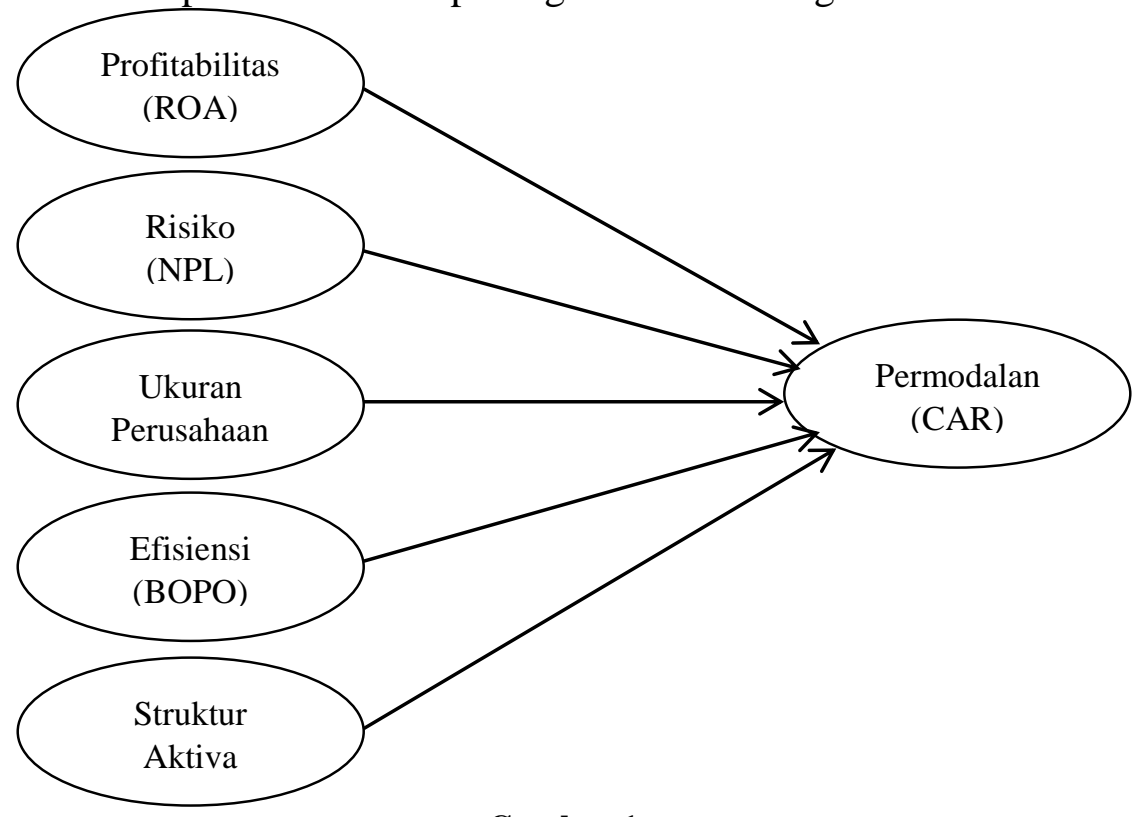

Gambar 1

Kerangka Pikir 


\section{METODA PENELITIAN}

Penelitian ini menggunakan pendekatan kuantitatif yaitu yang melakukan pengujian terhadap hubungan kausal dari variabel-variabel penelitian yang terukur. Objek penelitian ini adalah industri perbankan nasional yang listed di Bursa Efek Indonesia. Populasi dalam penelitian ini adalah industri perbankan yang go public di Bursa Efek Indonesia sampai dengan tahun 2013 dengan jumlah bank sebanyak 38. Teknik sampling yang digunakan dalam penelitian ini adalah purposive sampling, yaitu penentuan sampel dengan kriteria tertentu berdasarkan pada tujuan penelitian. Kriteria yang digunakan dalam penelitian ini adalah bank yang sudah go publik sebelum tahun 2008 dan bank tersebut mempublikasikan laporan keuangan tahun 2008 sampai 2013. Jumlah sampel dalam penelitian ini sebanyak 23 bank.

Variabel Dependen yang digunakan dalam penelitian ini adalah permodalan bank (CAR). Ukuran permodalan bank yang digunakan dalam penelitian ini adalah rasio kecukupan modal bank terhadap Aktiva Tertimbang Menurut Risiko (ATMR) atau CAR (Y).

$C A R=\frac{\text { Modal Sendiri }}{A T M R}$ 1

Sedangkan Independent variabel yang digunakan dalam penelitian ini adalah profitabilitas $\left(\mathrm{X}_{1}\right)$. Profitabilitas bank diproksikan dengan Return on Aset (ROA). Penggunaan rasio ROA ini didasarkan pada pertimbangan bahwa Bank Indonesia dalam melakukan penilaian profitabilitas bank lebih mengutamakan ROA ketimbang ROE.

$R O A=\frac{\text { Earning After Tax }}{\text { Total Assets }}$.

Risiko bank dalam penelitian ini diproksikan dengan besanya Non Performance Loans (NPL) $\left(\mathrm{X}_{2}\right)$. NPL merupakan rasio antara kredit bermasalah dengan jumlah kredit yang disalurkan. Semakin besar NPL menunjukkan bahwa manajemen kurang baik dalam pengelolaan kreditnya, yang akhirnya akan berdampak pada kerugian bank.

$N P L=\frac{\text { Total Kredit Bermasalah }}{\text { Total Kredit }}$ 3

Variabel Ukuran perusahaan $\left(\mathrm{X}_{3}\right)$ menggambarkan besar kecilnya suatu perusahaan yang dapat dinilai dari total aset yang dimiliki perusahaan. Ukuran perusahaan diproksikan dengan 1/logaritma natural total Aktiva (Hall dan Weiss: 1967).

Ukuran Perusahaan $=\frac{1}{\text { Ln Total Aktiva }}$..

Variabel efisiensi bank diproksikan dengan membandingkan antara Biaya Operasional dengan Pendapatan Operasional (BOPO) $\left(\mathrm{X}_{4}\right)$. BOPO yang semakin tinggi menunjukkan bank semakin tidak efisien dan sebaliknya. Semakin efisien suatu bank menunjukkan bahwa manajemen bank telah mengunakan semua faktor produksinya dengan efektif dan efisien. BOPO yang semakin besar menunjukkan semakin besar jumlah biaya operasi, sehingga cenderung akan menurunkan profitabilitas bank. 
$B O P O=\frac{\text { Biaya Operasi }}{\text { Pendapatan Operasi }}$ 5

Variabel Struktur Aktiva $\left(\mathrm{X}_{5}\right)$ menunjukkan perbandingan antara aktiva tetap dengan total aktiva bank.

Struktur Aktiva $=\frac{\text { Aktiva Tetap }}{\text { Total Aktiva }}$ 6

Pengujian asumsi klasik dilakukan dalam penelitian untuk mengetahui kelayakan model regresi yang digunakan dalam penelitian ini. Uji asumsi klasik dilakukan untuk memastikan dalam model regresi tidak terdapat autokorelasi, multikolineritas dan heteroskedastisitas serta datanya berdistribusi normal (Ghazali 2005).

Secara sistematis model yang dikembangkan untuk menganalisis pengaruh variabel Profitabilitas, risiko, efisiensi dan ukuran perusahaan terhadap permodalan bank digunakan model regresi berganda. Model tersebut dirumuskan sebagai berikut:

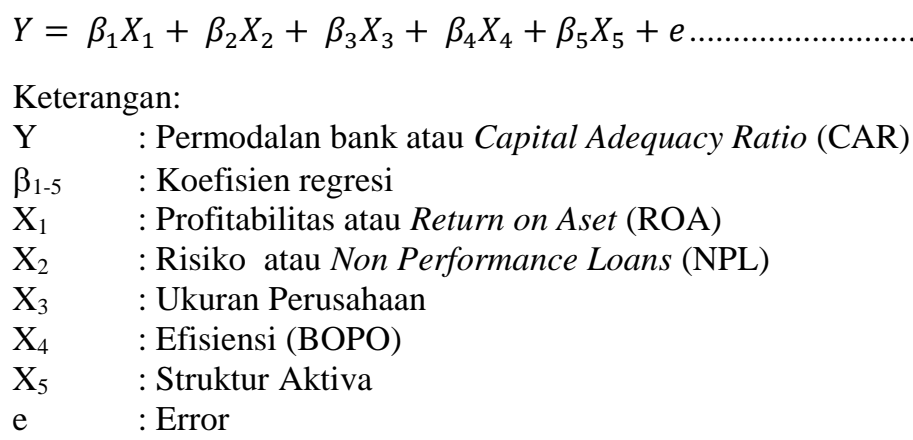

\section{ANALISIS DAN PEMBAHASAN}

\section{Deskripsi data}

Rerata CAR perbankan swasta nasional tahun 2008-2013 diatas ketentuan Bank Indonesia, yaitu sebesar 16,84 persen. Hal ini menunjukkan bahwa secara permodalan bank-bank umum swasta nasional cukup kuat. Bahkan CAR terendah masih sebesar 10,34 persen. Sedangkan dari sisi profitabilitas rerata ROA sebesar 1,21 persen. Hal ini menunjukkan kinerja perbankan secara umum cukup baik, karena perbankan mampu membukukan laba bersih sebesar 1,21 persen aset dimilikinya. Bank Pundi Indonesia (BEKS) sempat mengalami kerugian pada tahun 2008-2011, sehingga ROAnya negatif. Bahkan pada tahun 2010, sehingga ROAnya negatif 10,66, namun setelah itu terus membukukan laba, sehingga profiatbilitsnya membaik.

Risiko bank yang ditunjukkan dengan NPL menunjukkan bahwa rerata NPL sebesar 2,61. Hal ini menunjukkan bahwa NPL Bank masih di bawah ketentuan Bank Indonesia sebesar 5 persen. Semakin kecil NPL menunjukkan semakin rendah kredit bermasalah perbankan nasional. Dengan NPL yang semakin kecil berarti permodalan bank akan semakin besar, karena tidak tergerogoti untuk menutup kredit yang bermasalah. 
Sedangkan dilihat dari ukuran menunjukkan bahwa perbankan nasional cukup bervarian. Rerata BOPO yang menunjukkan tingkat efisiensi bank sebesar 81,02 persen. Artinya bank nasional untuk menghasilkan pendapatan membutuhkan biaya sebesar 81,02 persen. BOPO yang semakin besar menunjukkan bank semakin tidak efisien dan sebaliknya. Ketika perbankan nasional masih mengandalkan pendapatan dari bunga kredit, dengan harga dana yang mahal akan membuat semakin tidak efisiennya suatu bank. Efisiensi perbankan nasional menunjukkan peningkatan, hal ini ditunjukkan dengan nilai BOPO yang semakin rendah.

Struktur aktiva menunjukkan perbandingan antara aktiva tetap dengan total aktiva. Rerata struktur aktiva sebesar 1,81 persen. Artinya aktiva tetap perbankan nasional hanya sebesar 1,81 persen dari seluruh aktiva bank. Karakteristik perbankan dimana aset bank lebih banyak didominasi kas atau setara kas dan kredit, yang merupakan aset lancar bank.

\section{Uji Normalitas Data}

Pengujian normalitas data dilakukan dengan menggunakan melihat diagram normal p-p plot. Jika data menyebar mengikuti arah garis diagonal, maka data normal. Model regresi yang baik adalah distribusi datanya normal atau mendekati normal. Hasil pengujian normalitas menunjukkan data tidak normal serta berdasarkan uji heteroskedasitas menunjukkan scatter plot antar nilai prediksi yang distandarisari (ZPRED) dengan nilai residual yang distandarisasi (SRESID) membentuk suatu pola, yaitu mengumpul. Hasil pengujian ulang dengan melogaritmakan variabel penelitian diperoleh hasil data berdistribusi normal, ditunjukkan dengan penyebaran titik-titik pada Normal P-P Plot yang berada di sekitar garis diagonal.

\section{Uji Asumsi Klasik}

Uji heteroskedasitas dilakukan dengan menggunakan scatter plot antar nilai prediksi yang distandarisari (ZPRED) dengan nilai residual yang distandarisasi (SRESID). Uji ini untuk mengetahui apakah terdapat hubungan antara variabel bebas dengan nilai residual. Hasil uji heteroskedasitas menunjukkan bahwa tidak terjadi heteroskedasitas, hal ini ditunjukkan scatterplot, dimana sebaran atau plot di scatterplot menyebar dan tidak membentuk suatu pola tertentu atau menyebar di atas dan di bawah angka nol pada sumbu studentized residual atau sumbu $\mathrm{Y}$ dan di kanan dan kiri sumbu standardized predicted value.

Pengujian Autokorelasi dengan menggunakan DW. Hasil analisis menunjukkan nilai DW sebesar 1.738 yang dapat dilihat di Tabel 3, dengan jumlah data (n) sebanyak 138 dan tabel Durbin Watson dengan signifikansi 0,05 diperoleh nilai dU 1,7819 dan dL sebesar 1,6476. Nilai DW hitung berada diantara dU (1,781) dan 4-dU $(2,219)$ sehingga dapat disimpulan tidak terjadi autokorelasi. Pengujian multikolineritas digunakan untuk mengetahui apakah ada korelasi yang tinggi diantara variabel bebas. Pengujian ini dapat dilakukan berdasarkan nilai Varian Inflation Factor (VIF). Hasil pengujian menunjukkan 
nilai VIFnya lebih kecil dari 10, sehingga dapat disimpulkan tidak terjadi multikolineritas.

\section{Pengujian Kesesuaian model}

Berdasarkan pengujian sebagaimana ditampilkan pada Tabel 3, untuk pengujian goodness of model menunjukkan bahwa secara simultan variabel profiatbilitas (ROA), Risiko (NPL), Ukuran Perusahaan, Efisiensi (BOPO) dan Struktur Aktiva berpengaruh terhadap Permodalan Bank (CAR). Hal ini ditunjukkan dengan nilai probabilitas $\mathrm{F}$ sebesar 0,000, dimana nilainya lebih kecil dari 0,05. Nilai koefisien determinasi adjusted $\left(\mathrm{R}^{2}\right.$ adjusted) sebesar 0,264. Artinya independent variable atau variabel bebas mampu menjelaskan dependent variable sebesar 26,4 persen, sedangkan sisanya sebesar 73,6 persen dijelaskan variabel lain diluar model penelitian.

Tabel 3

Hasil Analisis

\begin{tabular}{|c|c|c|c|c|c|}
\hline & $\begin{array}{c}\text { Standardized } \\
\text { Coefficients Beta }\end{array}$ & $\mathbf{t}$ & Sig. & VIF & Keterangan \\
\hline ROA & 0,394 & 4,192 & 0,000 & 1,649 & Signifikan \\
\hline NPL & $-0,242$ & $-3,094$ & 0,002 & 1,142 & Signifikan \\
\hline UKPER & 0,380 & 4,536 & 0,000 & 1,308 & Signifikan \\
\hline ВOPO & 0,036 & 0,467 & 0,641 & 1,098 & Tidak Signifikan \\
\hline StrAk & 0,291 & 3,304 & 0,001 & 1,444 & Signifikan \\
\hline DW & $: 1,838$ & & & & \\
\hline $\mathrm{R}^{2}$ & $: 0,291$ & & & & \\
\hline $\mathrm{R}_{\text {Adjusted }}^{2}$ & $: 0,264$ & & & & \\
\hline $\mathrm{F}_{\text {Hitung }}$ & $: 10,857$ & & & & \\
\hline Sig F & $: 0,000$ & & & & \\
\hline
\end{tabular}

\section{Uji Hipotesis}

Sedangkan untuk uji secara parsial, yaitu untuk menguji hipotesis penelitian menunjukkan hasil sebagai berikut:

\section{Uji t Pengaruh profitabilitas terhadap permodalan (CAR)}

Nilai signifikansi variabel profitabilitas (ROA) adalah sebesar $0,000<0,05$ hal ini menunjukkan bahwa ROA berpengaruh signifikan terhadap CAR dengan arah positif. Berdasarkan hasil di atas maka hipotesis 1 diterima, artinya variabel ROA berpengaruh signifikan terhadap CAR.

\section{Uji t Pengaruh risiko (NPL) terhadap permodalan (CAR)}

Nilai signifikansi variabel risiko (NPL) adalah sebesar $0,002<0,05$ hal ini menunjukkan bahwa NPL berpengaruh signifikan terhadap CAR dengan arah negatif. Berdasarkan hasil di atas maka hipotesis 2 diterima, artinya variabel NPL berpengaruh signifikan terhadap CAR.

\section{Uji t Ukuran Perusahaan terhadap permodalan (CAR)}


Nilai signifikansi variabel risiko (NPL) adalah sebesar $0,000<0,05$ hal ini menunjukkan bahwa ukuran perusahaan berpengaruh signifikan terhadap CAR dengan arah positif. Berdasarkan hasil di atas maka hipotesis 3 diterima, artinya variabel ukuran perusahaan berpengaruh signifikan terhadap CAR.

\section{Uji t Efisiensi (BOPO) terhadap Permodalan (CAR)}

Nilai signifikansi variabel efisiensi (BOPO) adalah sebesar 0,641>0,05 hal ini menunjukkan bahwa BOPO tidak berpengaruh signifikan terhadap CAR. Berdasarkan hasil di atas maka hipotesis 4 ditolak, artinya variabel BOPO tidak berpengaruh terhadap CAR.

\section{Uji t Struktur Aktiva terhadap Permodalan (CAR)}

Nilai signifikansi variabel efisiensi (BOPO) adalah sebesar $0,001<0,05$ hal ini menunjukkan bahwa struktur aktiva berpengaruh signifikan terhadap CAR. Berdasarkan hasil di atas maka hipotesis 5 ditolak, artinya variabel struktur aktiva berpengaruh terhadap CAR.

\section{Pengaruh Profitabilitas terhadap Permodalan (CAR)}

Hasil penelitian menunjukkan bahwa profitabilitas berpengaruh terhadap permodalan bank (CAR) dengan arah positif. ROA merupakan ukuran profitabilitas bank menunjukkan kemampuan bank dalam menghasilkan laba dari aset yang dimilikinya. Laba perusahaan sebagian dapat dialokasikan kepada pemegang saham berupa dividen, selain digunakan untuk menambah modal sebagai laba ditahan yang akan menambah modal bank. Sehingga bank dengan profitabilitas yang tinggi cenderung CAR-nya akan semakin besar, karena adanya penambahan ekuitas yang berasal dari laba yang ditahan. Sebaliknya jika bank mengalami kerugian, maka akan mengikis modalnya untuk menutup kerugian, sehingga CAR-nya cenderung akan semakin berkurang. Semakin tinggi ROA menunjukkan semakin tinggi produktivitas perusahaan dalam menghasilkan laba. Sebaliknya bank dengan ROA yang rendah akan menurunkan permodalan bank.

Hasil penelitian menunjukkan bahwa bank-bank yang sehat, dimana tingkat profitabilitasnya semakin baik akan cenderung permodalannya akan semakin kuat. Sebaliknya bank dengan profitabilitas yang cenderung rendah, maka permodalan bank akan cenderung rendah. Hal ini sejalan dengan teori bahwa bank dengan profitabilitas yang baik atau tinggi cenderung akan memiliki prospek yang baik, karena permodalannya cenderung akan semakin kuat. Hasil penelitian ini mendukung penelitian yang dilakukan Ali (2006) dan F. Artin Shitawati (2006) ROA berpengaruh terhadap CAR. Namun tidak mendukung penelitian (Fatimah 2014).

\section{Pengaruh Risiko (NPL) terhadap Permodalan (CAR)}

NPL merupakan rasio antara kredit bermasalah dengan kredit disalurkan bank. Rasio ini digunakan untuk mengukur risiko kredit, dimana semakin tinggi NPL menunjukkan semakin tinggi risiko yang dihadapi bank. Hasil penelitian menunjukkan bahwa NPL berpengaruh terhadap CAR dengan arah negatif, artinya semakin rendah 
NPL maka CAR akan cenderung meningkat dan sebaliknya. NPL yang tinggi mengindikasikan bahwa pengelolaan kredit pada bank tidak optimal, sehingga akan mengikis permodalan bank. Sebaliknya jika NPL kecil menunjukkan risiko bank rendah, sehingga akan berdampak positif terhadap permodalan bank.

Lingkungan bisnis yang bergejolak cenderung akan meningkatkan risiko yang dihadapi bank, sehingga dituntut untuk menyediakan permodalan yang besar. Dengan permodalan yang besar bank cenderung akan mampu bertahan dari terpaan lingkungan bisnis yang bergejolak. Kondisi lingkungan bisnis yang semakin global, membuat interdependensi sangat tinggi, yang pada gilirannya stabilitas ekonomi semakin rentan. Hal inilah yang membuat industri perbankan cenderung meningkatkan CAR-nya.

Hasil penelitian ini mendukung temuan Krisna (2008) dimana risiko (NPL) berpengaruh terhadap CAR. Namun penelitian ini tidak mendukung penelitian yang dilakukan oleh Damayanti dan Chaniago (2014) dimana NPL tidak berpengaruh signifikan terhadap CAR.

\section{Pengaruh Ukuran Perusahaan terhadap Permodalan (CAR)}

Hasil penelitian menunjukkan bahwa ukuran perusahaan (size) berpengaruh terhadap permodalan bank (CAR) dengan arah positif. Hal ini menunjukkan bahwa bank dengan ukuran yang semakin besar, yang diukur dari aset yang dimiliki, maka semakin besar kemampuan bank untuk memenuhi permodalannya. Bank dengan aset yang semakin besar akan cenderung mampu mendorong likuiditas bank, yang selanjutnya akan dapat meningkatkan permodalan bank. Hasil penelitian ini relevan dengan penelitian (Muyanja Ssenyonga \& Prabowo 2006). Hasil penelitian Ahmad et al. (2008) menunjukkan bahwa ukuran bank dalam hubungannya dengan total aset yang dimiliki dan tingkat likuiditas bank merupakan faktor penting dalam menentukan rasio permodalan.

Ukuran perusahaan menunjukkan besarnya suatu perusahaan berdasarkan total aktiva. Perusahaan dengan total aktiva besar menunjukkan perusahaan telah mencapai tahap kedewasaan dan relatif lebih stabil serta lebih mampu menghasilkan laba dibanding perusahaan dengan total aset yang kecil (Pangemanan \& Mawikere 2011). Perusahaan yang besar dianggap lebih berpengalaman dalam menghadapi risiko serta mengelola investasi yang diberikan para stockholder untuk meningkatkan kemakmuran. Sehingga perusahaan besar cenderung lebih menjanjikan kinerja yang baik, yang selanjutnya akan berpengaruh positif terhadap permodalannya.

\section{Pengaruh Efisiensi (BOPO) terhadap Permodalan (CAR)}

Berdasarkan hasil pengujian menunjukkan bahwa efisiensi tidak berpengaruh terhadap CAR. Hal ini menunjukkan bahwa efisensi bank secara langsung tidak memengaruhi permodalan bank. Efisiensi perbankan nasional pada tahun 2008-2013 ratarata sebesar 81,02, dimana rasio BOPO pada tahun 2014 mengalami peningkatan menjadi 76,9 persen dibandingkan dengan tahun 2013 sebesar 74,1 persen. Efisiensi yang tidak 
berpengaruh pada CAR ini dapat terjadi menunjukkan bahwa bank masih mampu mengcover biaya-biaya operasional yang belum menyentuh permodalan bank. Kondisi demikian membuat efisiensi tidak berpengaruh terhadap CAR. Hasil penelitian ini mendukung temuan penelitian yang dilakukan oleh Krisna (2008), Fitrianto dan Mawardi (2006) menyatakan bahwa rasio BOPO tidak berpengaruh terhadap rasio kecukupan modal. Namun tidak mendukung temuan penelitian F. Artin Shitawati, (2006), Ghosh et al. (2003) efisiensi berpengaruh terhadap rasio kecukupan modal serta penelitian (Ahmad et al., (2008)) dimana efisensi biaya operasional akan menambah modal bank.

\section{Pengaruh Struktur aktiva terhadap Permodalan (CAR)}

Struktur aktiva menunjukkan perbandingan antara aktiva tetap dengan total aktiva. Hasil penelitian menunjukkan bahwa struktur aktiva berpengaruh terhadap permodalan bank (CAR) dengan arah positif. Hal ini mengindikasikan bahwa semakin besar struktur aktiva akan cenderung CAR bank akan semakin besar dan sebaliknya. Struktur aktiva yang besar menunjukkan aktiva bank akan semakin besar, untuk membiayai aktiva tetap biasanya lebih cenderung menggunakan sumber dana yang berasal dari modal sendiri, dibandingkan dari hutang atau DPK. Sehingga ketika aktiva tetap bank meningkat, sehingga struktur aktiva meningkat maka CAR bank cenderung akan meningkat pula dan sebaliknya.

Aktiva tetap merupakan penggunaan dana yang sifatnya jangka panjang. Struktur dana bank, yang terdiri dari dana pihak pertama, yang berasal dari pemilik atau berupa modal, dana pihak kedua atau hutang dan DPK. Dalam pengelolaan dana bank atau manajemen dana, maka DPK cenderung akan digunakan untuk memenuhi cadangan minimum dan kredit, karena karakter DPK yang sifatnya jangka pendek. Sedangkan Dana dari pemilik atau modal lebih cenderung diinvestasikan untuk investasi jangka panjang termasuk didalamnya untuk membiayai aktiva tetap. Sehingga ketika aktiva tetap bank meningkat akan cenderung permodalan bank juga akan meningkat.

\section{SIMPULAN, KETERBATASAN DAN SARAN}

\section{Simpulan}

Pertama, profitabilitas bank berpengaruh positif terhadap permodalan bank. Kedua risiko bank berpengaruh dengan arah negatif terhadap permodalan. Ketiga ukuran perusahaan (Size) berpengaruh positif terhadap permodalan bank. Keempat efisiensi bank tidak berpengaruh terhadap permodalan dan struktur aktiva berpengaruh terhadap permodalan bank.

\section{Keterbatasan dan Saran.}

Objek penelitian ini terbatas pada industri perbankan nasional yang go public dengan rentang analisis tahun 2008-2013 dengan jumlah sampel 23 bank. Variabel yang digunakan untuk memprediksi permodalan bank hanya variabel internal bank. Untuk penelitian selanjutnya dapat dilakukan dengan melakukan analisis pada pada industri 
perbankan dengan cakupan yang lebih luas. Variabel penelitian dapat digunakan variabel lain, baik itu yang sifatnya faktor internal bank maupun eksternal bank.

\section{DAFTAR PUSTAKA}

Agus Sartono. 2008. Manajemen Keuangan: Teori dan Aplikasi. Edisi Keem. BPFE Yogyakarta.

Ahmad, Rubi, M. Ariff, dan Michael J. Skully. 2008. "The determinants of bank capital ratios in a developing economy." Asia-Pacific Financial Markets 15 (3-4): 25572. https://doi.org/10.1007/s10690-009-9081-9.

Aini, Nur. 2013. "Pengaruh car, nim, ldr, bopo dan kualitas aktiva produktif terhadap perubahan laba ( studi empiris pada perusahaan perbankan yang terdaftar di bei) tahun 2009-2011." Dinamika akuntansi, keuangan dan perbankan 2 (1): 14-25. https://doi.org/ISSN : 1979-4878.

Ali, Masyhud. 2006. Manajemen risiko: Strategi perbankan dan dunia usaha menghadapi tantangan globalisasi bisnis.

Almilia, Spica Luciana, dan Winny Herdinigtyas. 2005. “Analisis Rasio Camel Terhadap Prediksi Kondisi Bermasalah Pada Lembaga Perbankan Perioda 2000-2002." Jurnal Akuntansi dan Keuangan 7 (2): 131-47. https://doi.org/10.9744/jak.7.2.pp. 131-147.

Berger, Allen N., dan Loretta J. Mester. 1997. "Inside the black box: What explains differences in the efficiencies of financial institutions?" Journal of Banking and Finance 21 (7): 895-947. https://doi.org/10.1016/S0378-4266(97)00010-1.

Brinkmann, Emile J., dan Paul M. Horvitz. 1995. "Risk-based capital standards and the credit crunch.” Journal of Money, Credit and Banking 27 (3): 848-63.

Damayanti, Dhita Dhora, dan Herizon Chaniago. 2014. "Pengaruh risiko usaha dan good corporate governance terhadap skor kesehatan bank pada bank umum swasta nasional devisa." Journal of Business and Banking 4 (2): 217-30.

Dendawijaya, Lukman. 2005. Manajemen perbankan.

Eugene F. Brigham, Joel F. Houston. 2011. Dasar-dasar Manajemen Keuangan.

F. Artin Shitawati. 2006. "Analisis faktor-faktor yang berpengaruh terhadap capital adequacy ratio (studi empiris : Bank umum di indonesia periode 2001 - 2004).”

Fatimah, Siti. 2014. "Pengaruh rentabilitas, efisiensi dan likuiditas terhadap kecukupan modal bank umum syariah.” Jurnal Ilmu Ekonomi Syariah 6 (1): 1-17.

Fira Puspita, SE. 2009. “Analisis faktor-faktor yang mempengaruhi kebijakan dividend payout ratio pada perusahaan yang terdaftar di bursa efek jakarta periode 20052007." 
Fitrianto, Hendra, dan Wisnu Mawardi. 2006. "Analisis pengaruh kualitas aset, likuiditas, rentabilitas dan efisiensi terhadap rasio kecukupan modal perbankan yang terdaftar di bursa efek jakarta.” Jurnal Studi Manajemen \& Organisasi 3 (1): 111.

Ghazali, Imam. 2005. Analisis multivariate SPSS. Semarang: Badan Penerbit Universitas Diponegoro.

Ghosh, Saibal, D. M. Nachane, Aditya Narain, dan Satyananda Sahoo. 2003. "Capital requirements and bank behaviour: An empirical analysis of Indian public sector banks." Journal of International Development 14 (2): 145-56. https://doi.org/10.1002/jid.947.

Godlewski, Christophe J. 2005. "Bank capital and credit risk taking in emerging market economies." Journal of Banking Regulation 6 (2): 128-45. https://doi.org/10.1057/palgrave.jbr.2340187.

Hall, Marshall, dan Leonard Weiss. 1967. "Firm Size and Profitability." Source: The Review of Economics and Statistics 49 (3): 319-31. https://doi.org/10.2307/1926642.

Hempel, George H., dan Jess B. Yawitz. 1977. Financial management of financial institutions. New York: Prentice Hall.

Idroes, Ferry Novindra. 2011. Manajemen risiko perbankan : Pemahaman pendekatan 3 pilar kesepakatan basel II terkait aplikasi regulasi dan pelaksanaannya di Indonesia.

Irawan, Keynes, dan Achmad herlanto Anggono. 2015. "A study of capital adequacy ratio and its determinants in indonesian banks: A panel data analysis." International Journal of Management and Applied Science 1 (9): 1-4.

J. Fred Weston, dan T.E. Copeland. 1997. Manajemen Keuangan. Ed. 9. Jakarta: Binarupa Aksara.

Krisna, Yansen. 2008. "Faktor-faktor yang mempengaruhi capital adequacy ratio (studi pada bank-bank umum di indonesia periode tahun 2003-2006).”

Kunlin, Lin. 2007. "Study on related party transactions with mainland china in taiwan enterprises."

Lindgreen, Carl-Johan. 1996. Bank soundness and macroeconomics policy. Washington: Intl Monetary Fund.

Margaretha, Farah, dan Diana Setiyaningrum. 2011. "Pengaruh resiko, kualitas manajemen, ukuran dan likuiditas bank terhadap capital adequacy ratio bank-bank yang terdaftar di bursa efek indonesia." Jurnal Akuntansi dan Keuangan 13 (1): $47-56$.

Muyanja Ssenyonga, dan Dibyo Prabowo. 2006. "Bank risk level and bank capital: The 
case of the Indonesian banking sector." Journal of Indonesian Economy and Business 21 (2): 122-27.

Naiker, Vic, Farshid Navissi, dan VG Sridharan. 2008. "The Agency Cost Effects of Unionization on Firm Value." Journal of Management Accounting Research 20 (1): 133-52. https://doi.org/10.2308/jmar.2008.20.1.133.

Pandey, I. M. 2002. "Capital Structure, Profitability and Market Structure : Evidence from Malaysia." Global Business and Finance Review 8 (2): 79-91.

Pangemanan, Sifrid, dan Lidia Mawikere. 2011. "Pengaruh ukuran perusahaan dan pertumbuhan perusahaan terhadap earnings per share pada industri tekstil di bursa efek indonesia." JUrnal Riset Akuntansi dan Auditing 2 (1): 81-96.

Polat, Ali, dan Hassan Al-khalaf. 2014. "What determines capital adequacy in the banking system of kingdom of Saudi Arabia? A panel data analysis on tadawul banks." Journal of Applied Finance \& Banking 4 (5): 27-43.

Sari, Yulimel. 2013. "Pengaruh profitabilitas, kecukupan modal dan likuiditas terhadap harga saham (perusahaan perbankan yang terdaftar di BEI)." Jurnal Akuntansi 1 (1): 5-6.

Saunders, Anthony, dan Marcia Cornet Millon. 2008. Financial institution management: A risk management approach.

Shingjergji, Ali, dan Marsida Hyseni. 2015. "The determinans of capital adequacy ratio in the albanian banking system during 2007-2014." International Journal of Economics, Commerce and Management III (1): 1-10.

Utama, Chandara. 2006. "Mengukur tingkat kesehatan bank di indonesia." Bina Ekonomi 10 (1): $1-120$.

Whalen, Gary, dan James B. Thomson. 1988. "Using financial data to identify changes in bank condition." Federal Reserve Bank of Cleveland, Economic Review 24 (2): $17-26$. 